\title{
Importance of within-lake processes in affecting the dynamics of dissolved organic carbon and dissolved organic and inorganic nitrogen in an Adirondack forested lake/watershed
}

\author{
Phil-Goo Kang ${ }^{1,2}$, Myron J. Mitchell ${ }^{1}$, Patrick J. McHale ${ }^{1}$, Charles T. Driscoll ${ }^{3}$, Shreeram Inamdar ${ }^{4}$, and \\ Ji-Hyung Park ${ }^{5}$ \\ ${ }^{1}$ State University of New York - College of Environmental Science and Forestry, Syracuse, NY 13210, USA \\ ${ }^{2}$ Research Strategy and Planning Division, National Institute of Environmental Research, Incheon 22689, Republic of Korea \\ ${ }^{3}$ Department of Civil and Environmental Engineering, Syracuse University, Syracuse, NY 13244, USA \\ ${ }^{4}$ Department of Plant and Soil Sciences, University of Delaware, Newark, DE 19716, USA \\ ${ }^{5}$ Department of Environmental Science \& Engineering, Ewha Womans University, Seoul 03760, Republic of Korea
}

Correspondence to: Phil-Goo Kang (philgkang@gmail.com, philgkang@korea.kr)

Received: 17 September 2015 - Published in Biogeosciences Discuss.: 28 October 2015

Revised: 11 March 2016 - Accepted: 23 March 2016 - Published: 11 May 2016

\begin{abstract}
Lakes nested in forested watersheds play an important role in mediating the concentrations and fluxes of dissolved organic matter. We compared long-term patterns of concentrations and fluxes of dissolved organic carbon (DOC) and dissolved organic (DON) and inorganic nitrogen (DIN) in aquatic ecosystems of the Arbutus Lake watershed to evaluate how a lake nested in a forested watershed affects the sources (e.g., production) and sinks (e.g., retention) of DOC and DON in the Adirondack Mountains of New York, USA. We observed no significant long-term changes of DOC and DON in the lake outlet since 1983 and 1994, respectively. However, the temporal patterns of DOC and DON concentrations in the lake inlet showed significant seasonality such as increases during the vegetationgrowing season along with notable decreases in the dormant season. A comparison of mass balances between inlet and outlet for the period from 2000 to 2009 suggested that the lake was a sink of DOC (mean of influx minus outflux: $+1140 \mathrm{~mol} \mathrm{Cha}^{-1} \mathrm{yr}^{-1}$ ). In contrast, the difference of discharge-weighted DON concentrations (mean of inlet minus outlet: $-1.0 \mu \mathrm{mol} \mathrm{NL}^{-1}$ ) between inlet and outlet was much smaller than the discharge-weighted DOC concentrations (average of inlet minus outlet: $+87 \mu \mathrm{mol} \mathrm{C \textrm {L } ^ { - 1 }}$ ). DON fluxes showed considerable variation among years (mean of influx minus outflux: +8 mol $\mathrm{Nha}^{-1} \mathrm{yr}^{-1}$; range of differences: -15 to $27 \mathrm{~mol} \mathrm{Nha}^{-1} \mathrm{yr}^{-1}$ ). DON exhibited low per-
\end{abstract}

cent retention ((influx-outflux)/influx) (mean: 6.9\%, range: -34.8 to +31.2 ) compared to DOC (mean: $30.1 \%$, range: +9.2 to +44.1 ). The resultant increase of DON within the lake was closely linked with a net decrease of DIN through monthly Pearson correlation analysis, suggesting the importance of biotic factors in mediating lake DON dynamics. Our results show different relative retentions of DOC compared with DON, along with a larger retention of DIN than DON, suggesting that DOC and DON might display substantially different biogeochemical relationships in oligo-mesotrophic lakes nested forested watersheds and therefore different roles for a sink behavior for DOC compared to a producer of DON.

\section{Introduction}

Dissolved organic matter (DOM) produced from terrestrial (Aitkenhead-Peterson et al., 2003) and aquatic (Bertilsson and Jones, 2003) sources plays an important role in supporting microbial activity, contributing to energy flux, and influencing material cycling (Findlay and Sinsabaugh, 2003; Wetzel, 2001). DOM interactions with toxic $\mathrm{Al}$ and $\mathrm{Hg}$ (Driscoll et al., 1988) and the creation of disinfection byproducts (Siddiqui et al., 1997) affect water quality and general ecosystem health. Dissolved organic carbon (DOC) also plays a role in the protection of aquatic biota due to the at- 
tenuation of ultraviolet-B radiation (Williamson, 1995). Dissolved organic nitrogen (DON) is an important component of the total solute $\mathrm{N}$ loss in some ecosystems, especially those with low concentrations of total dissolved N (TDN) (Campbell et al., 2000; Hedin et al., 1995; Mitchell et al., 2001; Neff et al., 2003). Little attention has been paid to differences in the transport and transformations of DOC, DON, and DIN along different compartments of forested watersheds, except a few recent studies that compared differential storm responses of DOC and DON (Inamdar et al., 2008; Goodman et al., 2011).

There has been considerable discussion on the mechanisms driving recent increases of DOC in acid-sensitive surface waters in North America and Europe (Driscoll et al., 2007; Erlandsson et al., 2011; Evans et al., 2007; Monteith et al., 2007, 2015). For example, Monteith et al. (2007) suggested that the recovery of the previous acidification of surface water in response to decreased acidic deposition might result from an increase in the solubility of soil organic matter due to the change of $\mathrm{pH}$, aluminum and ionic strength (Kalbitz et al., 2000; Mulder et al., 2001). Erlandsson et al. (2011) suggested the importance of understanding the effects of acidification on reexamining DOC reference levels. Other possible mechanisms driving this increase in DOC concentrations include increasing temperatures (Freeman et al., 2001), changing hydrology associated with increases in precipitation and runoff (Schindler et al., 1997), changes in land uses (Worrall et al., 2004), alteration of dry and rewetting cycles (von Schiller et al., 2015), increasing primary production induced by increases of atmospheric $\mathrm{CO}_{2}$ (Freeman et al., 2004) and increased occurrences of droughts (Worrall and Burt, 2005).

While many studies have explored the dynamics and fate of DOC in aquatic ecosystems (e.g., Findlay and Sinsabaugh, 2003), very few have simultaneously investigated the changes in DON (Sarkkola et al., 2012). The short-term studies that have compared DOC versus DON changes indicate that DOC export from forested lakes in Adirondack Mountains was negatively related to hydraulic residence time but not for DON, suggesting that different biogeochemical responses for DOC and DON (Ito et al., 2005). Evaluating the causes of these differences is important for understanding spatial and temporal patterns of DOC and DON in surface waters including the role of within-lake processes. The generation of organic matter by autochthonous processes is an important factor for the formation of DOC and DON within lakes. Generally DOC and DON concentrations increase in eutrophic lakes due to the relatively high autochthonous contributions in spite of enhanced microbial transformations to consume DOC and DON, while for oligotrophic lakes with low DOC and DON concentrations show a net decrease due to microbial decomposition, sedimentation, and photolysis (e.g., Thurman, 1985). Within-lake processes can affect nutrient dynamics including changes in $\mathrm{C}: \mathrm{N}$ ratios (Ito et al., 2007). Previous studies have shown differences in lability of DON and DOC (Kang and Mitchell, 2013; Gregorich et al., 2003; Kirchman, 2003; Petrone et al., 2009). DOM from drainage lakes can alter the amount and the chemical characteristics of the DOM and the processing of other elements in downstream surface waters.

Arbutus Lake, an oligotrophic/mesotrophic lake, in the Adirondack Mountains of New York State, is the one of the original Adirondack Long-Term Monitoring program (ALTM) lakes established in 1982 (Driscoll et al., 2003; Kelting and Laxson, 2014; Owen et al., 1999). Arbutus Lake watershed has been the site of various hydrologic and biogeochemical studies of DOC and DON. Piatek et al. (2009) showed that wetlands in the inlet (Archer Creek) catchment played an important role in controlling DOC concentrations within the Arbutus Lake watershed. Mitchell et al. (2006) reported on relationships between precipitation patterns and the export of DOC after late summer storms due to increases in water derived from upper soil layers and concomitant decrease in the proportion of ground water contributions. DOC export corresponded to interannual changes of temperature, precipitation and discharge in the winter (Park et al., 2005). The export of DON constituted $47 \%$ to the total solute N flux in the Arbutus Lake watershed for the period from 1985 to 1998 (Mitchell et al., 2001), and was enhanced by biotic processes affecting dissolved inorganic nitrogen (DIN) transformations at higher temperature in summer (Park et al., 2003). Ito et al. (2005) suggested that the decrease of the $\mathrm{C}: \mathrm{N}$ ratios among Adirondack lakes, including Arbutus Lake, was related to the contribution of autochthonous sources with low $\mathrm{C}: \mathrm{N}$ ratio, compared with allochthonous terrestrial sources. Most recently Kang and Mitchell (2013) studied DOM characteristics in the Arbutus Watershed in the Adirondack Mountains as water passed from upland streams, through a wetland, to the lake inlet and finally the lake outlet. There was a net export of high concentrations of aromatic, refractory and high-molecular-weight (HMW) DOC and DON produced from the wetland into the lake. Also they observed the decomposition of refractory HMW DOC and the increase of bioavailable DOC and DON within the lake.

The objectives of our current study were to (1) evaluate long-term changes in DOC concentrations and fluxes at the outlet of Arbutus Lake using monthly based ALTM data, (2) compare DOC, DON, and DIN concentrations and fluxes between inlet and outlet in Arbutus Lake using weekly observations from ongoing hydrobiogeochemical investigations in the Arbutus Watershed, and (3) evaluate the role of withinlake processes in affecting the dynamics (i.e., sources and sinks) of DOC and DON in the lake. We hypothesized that both monthly and yearly changes of DOC and DON within the lake differ due to the relative importance of different internal processes between these two solutes, i.e., DOC is decomposed to dissolved inorganic carbon (DIC) which may be released to the atmosphere as carbon dioxide or retained as DIC in the lake, while DON is decomposed to DIN which may be utilized by a range of biotic processes including 
uptake, denitrification, etc. Our study evaluates how a lake nested in a forest watershed affects dynamics of DOC and DON and provides new information on long-term DOC and DON processes within a lake with a particular focus on linking internal processes between DIN and DON based on data collected in our study as well as information from previous studies on the Arbutus Lake.

\section{Methods}

\subsection{Site description of Arbutus Lake}

The Arbutus Lake watershed $\left(43^{\circ} 58^{\prime} 48^{\prime \prime} \mathrm{N}, 74^{\circ} 13^{\prime} 48^{\prime \prime} \mathrm{W}\right)$ is located within the Huntington Wildlife Forest in the Adirondack Mountains of New York State. Arbutus Lake has a surface area of $50 \mathrm{ha}$, an average depth of $3.0 \mathrm{~m}$, and a maximum depth of $8.4 \mathrm{~m}$ (Driscoll and van Dreason, 1993). The lake has been classified as a medium till drainage lake by Newton and Driscoll (1990). For the period from 2001 to 2010 the total phosphorus concentrations ranged from 11 to $14 \mu \mathrm{g} \mathrm{L}^{-1}$ and chlorophyll $a$ concentrations ranged from 2.2 to $4.4 \mathrm{mg} \mathrm{m}^{-3}$ during the summer (Kelting and Laxson, 2014), indicating a trophic status within the oligo- and mesorange (OECD, 1982). The Arbutus Lake watershed has an area of $352 \mathrm{ha}$ and the elevations range from 513 to $748 \mathrm{~m}$ (Park et al., 2005). The annual temperature averaged $5.1^{\circ} \mathrm{C}$ from 1984 to 2013 and total annual precipitation averaged $1086 \mathrm{~mm}$ from 1981 to 2013 in Newcomb, NY (3 km distance from Huntington Wildlife forest) (NYSERDA, 2015).

The Archer Creek catchment (135 ha) represents a major source of water $(45 \%)$ to Arbutus Lake (McHale et al., 2000). The overstory vegetation in the upper slopes consists of mixed northern hardwoods including American beech ( $\mathrm{Fa}$ gus grandifolia), sugar maple (Acer saccharum), red maple (Acer rubrum), yellow birch (Betula alleghaniensis), and white pine (Pinus strobus). Lower slopes close to the lake are dominated by conifer stands such as eastern hemlock (Tsuga canadensis), red spruce (Picea rubens), and balsam fir (Abies balsamea) (Park et al., 2005). The surficial geology consists of thin to medium deposits of glacial till with a high sand content; the bedrock geology is largely composed of igneous rocks with some calcium-rich minerals (Driscoll et al., 1993). The wetland (Greenwood Mucky peats) is located in valley bottom and is $4 \%$ of the entire subcatchment area, and speckled alder (Alnus incana ssp. rugosa) is the dominant vegetation in the wetland (Bischoff et al., 2001).

\subsection{Hydrological and chemistry data}

The stage height and discharge at the outlet of Arbutus Lake have been measured using a V-notch weir since 1991 (Fig. 1). The inlet, located in the Archer Creek catchment, has been monitored using an $\mathrm{H}$-flume equipped with an automated discharge logging device since October 1994 (Mitchell et al., 2001) (Fig. 1). To calculate annual discharge-weighted DOC

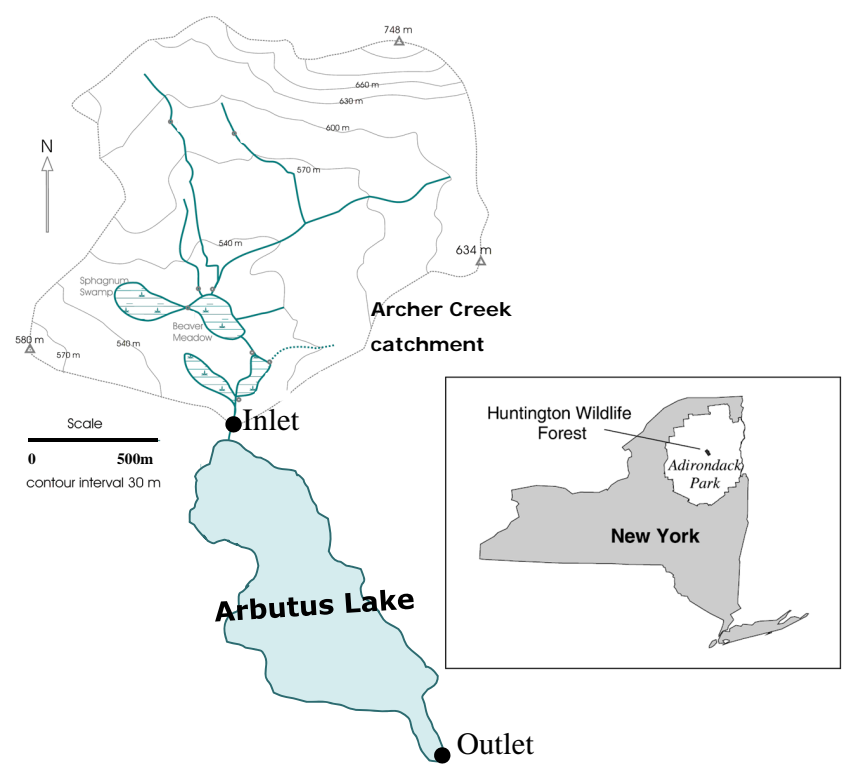

Figure 1. Study sites in the Arbutus Lake watershed in Huntington Wildlife Forest, Adirondack Park, New York, USA.

concentration at the outlet using ALTM data, we estimated monthly discharge at the lake outlet from 1984 to1990 using modeled discharge values and measured values for subsequent periods (Mitchell et al., 1996).

The outlet of Arbutus Lake has been monitored monthly by the ALTM program since February 1983 including DOC concentrations, and the analytical method described in Driscoll and van Dreason (1993). For the long-term change of DOC at Arbutus Lake, we used the monthly ALTM data from February 1983 to December 2012.

The inlet has been sampled weekly for chemical analyses, including DON concentrations since October 1994 and DOC concentration since May 1999. The outlet has been monitored weekly for chemical analyses, including DON concentrations since October 1991 and DOC concentration since May 1999. Water samples were kept on ice in the field transported to the Biogeochemistry Laboratory at SUNY ESF in Syracuse, NY, filtered through a precombusted glassfiber filter (Whatman GF/F) within one week after collection, and stored at $4{ }^{\circ} \mathrm{C}$ until further analysis.

The Biogeochemistry Laboratory, which is a participant in the USGS QA/QC program, analyzed $\mathrm{C}$ and $\mathrm{N}$ solutes as follows: $\mathrm{NO}_{3}^{-}$using a Dionex IC; $\mathrm{NH}_{4}^{+}$with an autoanalyzer using the Berthelot Reaction followed by colorimetric analysis; total dissolved nitrogen (TDN) using the persulfate oxidation procedure, followed by colorimetric analysis on an autoanalyzer; and DOC using the Tekmar-Dohrmann Phoenix 8000 TOC analyzer ${ }^{\circledR}$. DON concentrations were calculated as the difference between TDN and DIN $\left(\mathrm{NO}_{3}^{-}+\mathrm{NH}_{4}^{+}\right)$(Inamdar and Mitchell, 2007). If DIN exceeded or equaled TDN $(<2.5$ and $<1.4 \%$ of all samples in inlet and outlet, respectively), the value of DON was treated as zero. The lowest DON con- 
centrations in the inlet and outlet were -7.0 and $-17.1 \mu \mathrm{mol}$ $\mathrm{NL}^{-1}$, respectively. The calculated error for DON concentrations was $\pm 6.6 \%$ (square root of the sum of the squared analytical precision of TDN $( \pm 4.2 \%), \mathrm{NH}_{4}^{+}( \pm 3.2 \%)$, and $\mathrm{NO}_{3}( \pm 3.9 \%)$ ) (Kang and Mitchell, 2013).

\subsection{Calculations}

To calculate mass balances of DOC, DON, and DIN for Arbutus Lake, we used the same period (2000-2009) for the inlet and outlet chemistry. We assumed that the chemistry of Archer Creek inlet (a major source of water to the lake) was representative of all surface and ground water sources to Arbutus Lake. We assumed that direct DOC (e.g., $1600 \mathrm{~mol}$ $\mathrm{Cha}^{-1} \mathrm{yr}^{-1}$ in Ithaca, NY; Likens et al., 1983) and DON (e.g., 93 to $135 \mathrm{~mol} \mathrm{~N} \mathrm{ha}^{-1} \mathrm{yr}^{-1}$ in New England, US; Campbell et al., 2000) inputs via precipitation to the lake would be small as for other northeastern US forests. We also used the results from the NADP/NTN site for wet only deposition directly to Arbutus Lake (http://nadp.sws.uiuc.edu/nadpdata/ annualReq.asp?site $=$ NY20).

To calculate and compare fluxes of DOC, DON and DIN between the inlet and outlet, firstly the monthly dischargeweighted concentrations (MDWC) of DOC, DON and DIN were calculated using weekly concentration data as follows:

$\mathrm{MDWC}=\sum\left(Q_{j} m \times C_{j}\right) / \sum Q_{i}$,

where $Q_{j}$ and $C_{j}$ are $Q$ (daily discharge) and $C$ (concentration), respectively, for the $j$ th weekly sample in a given month and $Q_{i}$ is daily $Q$ in a given month. MDWC was also used to compare the monthly differences between the inlet and outlet.

To calculate annual discharge-weighted concentration (ADWC), MDWC (for ALTM data, monthly concentrations were used) and monthly discharges were used as follows:

$\mathrm{ADWC}=\sum\left(\mathrm{MDWC} \times Q_{i}\right) / \sum Q_{i}$,

where $Q_{i}$ is monthly $Q$ in a given year.

Finally, fluxes from the inlet and the outlet from 2000 to 2009 were also computed per unit area as follows:

$\operatorname{Flux}\left(\mathrm{molha}^{-1} \mathrm{yr}^{-1}\right)=\sum\left(\mathrm{ADWC} \times Q_{i}\right) / A$,

where $A$ is the watershed area of either the major lake (inlet $=135 \mathrm{ha}$ ) or the entire Arbutus watershed (outlet $=352$ ha).

To quantitatively understand how much solute was retained or decomposed due to the within-lake process, the annual percent retention of lake water (hydraulic retention), DOC, DON, and DIN within the lake was also computed:

Retention $(\%)=($ influx - outflux $) /$ influx $\times 100$,

where influx and outflux are fluxes of lake water and solutes at the inlet and the outlet, respectively. Positive values indicated a sink, and negative values indicated a source within the lake.
The annual retention amount of DOC, DON and DIN was calculated as follows:

Retention amount $(\mathrm{mol})=($ influx - outflux $)$

$\times 50$ (lake surface area).

The annual residence time of the lake was also calculated as follows:

Residence time (years) $=V / Q$,

where $V$ is the lake volume $\left(134.5 \times 10^{4} \mathrm{~m}^{3}\right)$ and $Q$ is the yearly outlet discharge (unit: $\mathrm{m}^{3} \mathrm{yr}^{-1}$ ).

\subsection{Statistical approaches and hypothesis testing}

To determine temporal changes in MDWC of DOC and DON at the inlet and outlet sites, a Seasonal Kendall trend analysis (a DOS executable program) was used (Helsel et al., 2006). To compare differences of MDWC between the inlet and outlet, one-way analysis of variance (ANOVA) with posthoc Tukey HSD test $(\alpha=0.05)$ was performed using Minitab (Version 16, Minitab Inc.). To evaluate correlation among DOC, DON and DIN concentration and climatic valuables (temperature and discharge) in the inlet and outlet and percent retention of lake water and fluxes and concentrations in DOC, DON and DIN of Arbutus Lake, Pearson correlation was analyzed for significance levels of $p<0.05$ using Minitab. We hypothesized that the dynamics of DON and DOC including changes in concentrations and mass balances will differ due to the relative importance of biogeochemical processes affecting each solute.

\section{Results}

\subsection{The long-term climatic factors and monthly DOC trend using ALTM data set}

Precipitation increased significantly from 1941 to 2009 (Table 1). However, there was no significant change in precipitation ( $p=0.08)$ or temperature $(p=0.07)$ from 1983 to 2009 during the period of DOC and DON investigation (Table 1). There was a significant relationship between precipitation and discharge during the same period (Table 1). An analysis of the Arbutus ALTM data set from 1983 to 2012 showed no significant change in DOC concentrations at the lake outlet (mean $408.1 \pm 31.3 \mathrm{SD} \mu \mathrm{mol} \mathrm{CL}^{-1}$; Table 1). Annual DOC influx for Arbutus Lake averaged $2501( \pm 602 \mathrm{SD}) \mathrm{mol}$ $\mathrm{Cha}^{-1} \mathrm{yr}^{-1}$.

\subsection{Trends of DOC, DON, and DIN concentrations using SUNY-ESF data set}

The DOC and DON concentrations at the inlet and outlet using weekly concentration data from SUNYESF are given in Fig. 2. The inlet DOC concentra-

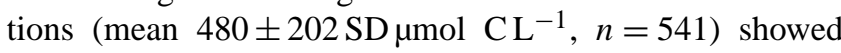


Table 1. Means and linear regression results (slope and p value) of annual precipitation and atmospheric temperature at Adirondack Ecological Center site since 1941 and 1983 (available at: http://www.esf.edu/aec/research/ALTEMP_projects.htm, 2016) and annual discharge, DOC concentration, and DOC flux at the Arbutus Lake outlet since 1983 using ALTM data set.

\begin{tabular}{lllrrl}
\hline & Period & Mean (SD) & Slope & $p$ value & Unit \\
\hline Precipitation* & $1941-2009$ & $1046.2(152.0)$ & 2.1 & 0.02 & $\mathrm{~mm}$ \\
& $1983-2009$ & $1109.8(125.8)$ & 5.4 & 0.08 & \\
Temperature & $1941-2009$ & $5.2(1.0)$ & -0.01 & 0.79 & ${ }^{\circ} \mathrm{C}$ \\
& $1983-2009$ & $5.5(0.7)$ & 0.03 & 0.07 & \\
Lake Discharge* & $1983-2009$ & $619.4(118.2)$ & -0.2 & 0.95 & $\mathrm{~mm} \mathrm{ha}^{-1}$ \\
DOC concentration & $1983-2012$ & $408.1(31.3)$ & 0.1 & 0.91 & $\mathrm{~mol} \mathrm{C} \mathrm{L}^{-1}$ \\
DOC flux & $1983-2012$ & $2501(602)$ & -2.8 & 0.84 & $\mathrm{~mol} \mathrm{Cha}^{-1} \mathrm{yr}^{-1}$ \\
\hline
\end{tabular}

* Determination coefficient $\left(r^{2}\right)$ between precipitation and lake discharge from 1983 to 2009 is $0.51(p<0.0001)$.
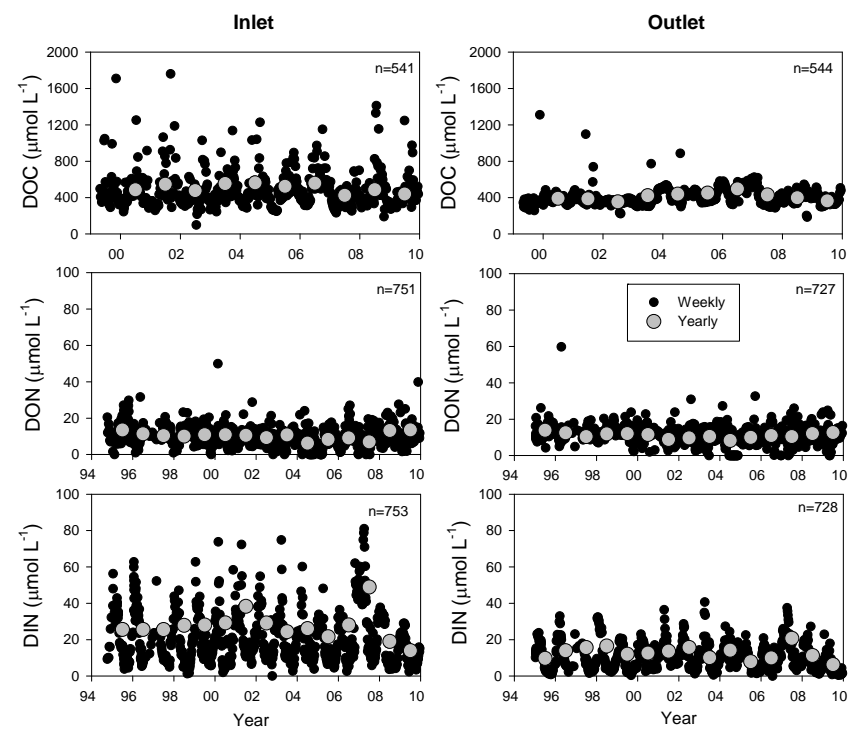

Figure 2. Weekly and annual yearly variation of DOC concentrations from 1999 to 2009 and DON and DIN concentrations from 1994 to 2009 at the inlet and outlet of Arbutus Lake. Annual values are discharged-weighted concentrations.

higher mean and greater monthly variation than the outlet (mean $402 \pm 93 \mathrm{SD} \mu$ mol CL ${ }^{-1}, n=545$ ). In contrast, the DON concentrations showed similar values at the in-

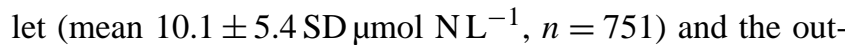
let (mean $11.5 \pm 5.0 \mathrm{SD} \mu$ mol NL $\mathrm{N}^{-1}, n=727$ ). The Seasonal Kendall test did not show any significant changes over time in DOC or DON concentrations: inlet DOC (slope: $1.8 \mu \mathrm{mol} \mathrm{C} \mathrm{L}^{-1} \mathrm{yr}^{-1}$, tau: 0.04, $p=0.68$ ), inlet DON (slope: $-0.03 \mu \mathrm{mol} \mathrm{N} \mathrm{L} \mathrm{yr}^{-1}$, tau: $-0.05, p=0.53$ ), outlet DOC

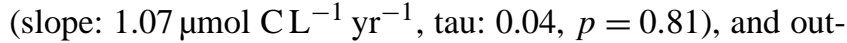

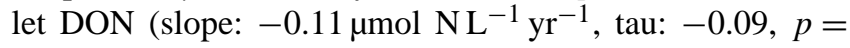
0.22 ).

The monthly concentrations of DOC, DON, and DIN and the monthly discharge values are shown in Fig. 3 . At the inlet there was a strong seasonality of DOC, DON, and DIN con- centrations. DOC and DON concentrations enhanced during a growing season and reduced during winter while DIN concentrations increased during winter and decreased from May to October. At the outlet the monthly DOC patterns that decreased from April and reaching a minimum in the fall (i.e., October) were substantially different than the temporal patterns of inlet DOC concentrations. At the inlet, DON concentrations showed a similar seasonal pattern to that of DOC concentrations; however, at the outlet the patterns were not similar, suggesting differences in the mechanisms regulating DOC and DON dynamics in the lake. Outlet DIN concentrations increased from January to April and decreased from May through November, indicative of DIN uptake and/or DIN reduction.

The statistical correlations among DOC, DON, DIN, monthly average temperature, and monthly total discharge for every month and for entire years are provided in Table 2 . For the inlet, DOC was positively correlated with DON, temperature, and discharge, and DON showed a positive relationship with temperature and discharge as also found for the inlet DOC. We observed a significantly negative relationship between DON and DIN concentrations. At the outlet, DOC was not correlated with DON, and the significantly negative relationships (May to December) between DON and DIN in the lake was found.

\subsection{Fluxes and mass balances of DOC, DON, and DIN in Arbutus Lake}

Based on weekly samples from 2000 to 2009 , we calculated the mass-balances of DOC, DON, and DIN at the inlet and the outlet (Tables 3 and 4). Our calculation of average residence time of $0.66 \mathrm{yr}^{-1}$ was almost same as that value estimated to be $0.6 \mathrm{yr}^{-1}$ in a previous study of Driscoll and van Dreason (1993) (Table 3). ADWC of DOC and DIN decreased from the inlet to the outlet, while DON increased, resulting in a decrease in molar $\mathrm{C}: \mathrm{N}$ ratios in the lake (Table 4). For Arbutus Lake the mean DOC outflux of $2477 \mathrm{~mol} \mathrm{Cha}^{-1} \mathrm{yr}^{-1}$ using weekly observations was similar (i.e., difference of $2 \%$ ) to the average flux calculated using 


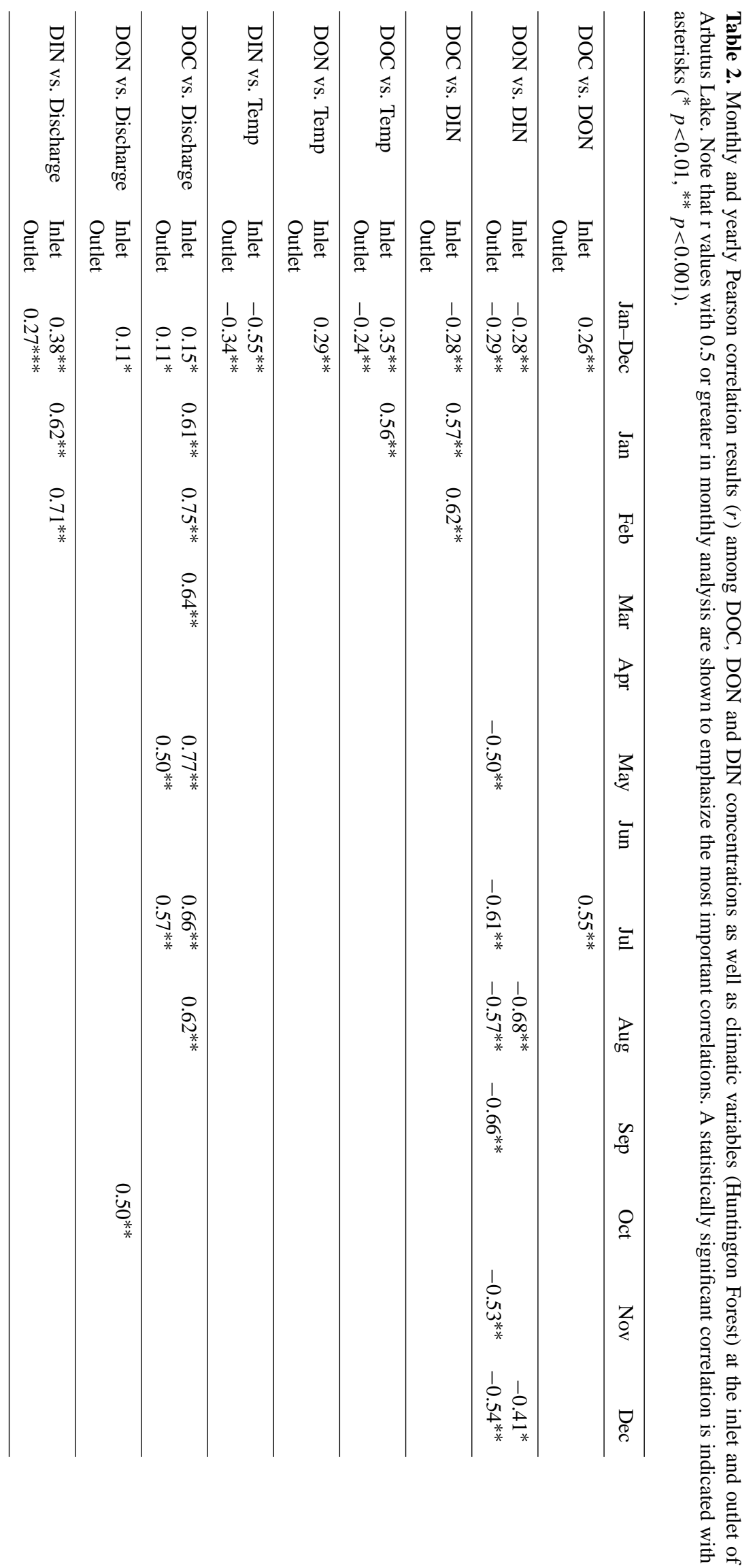



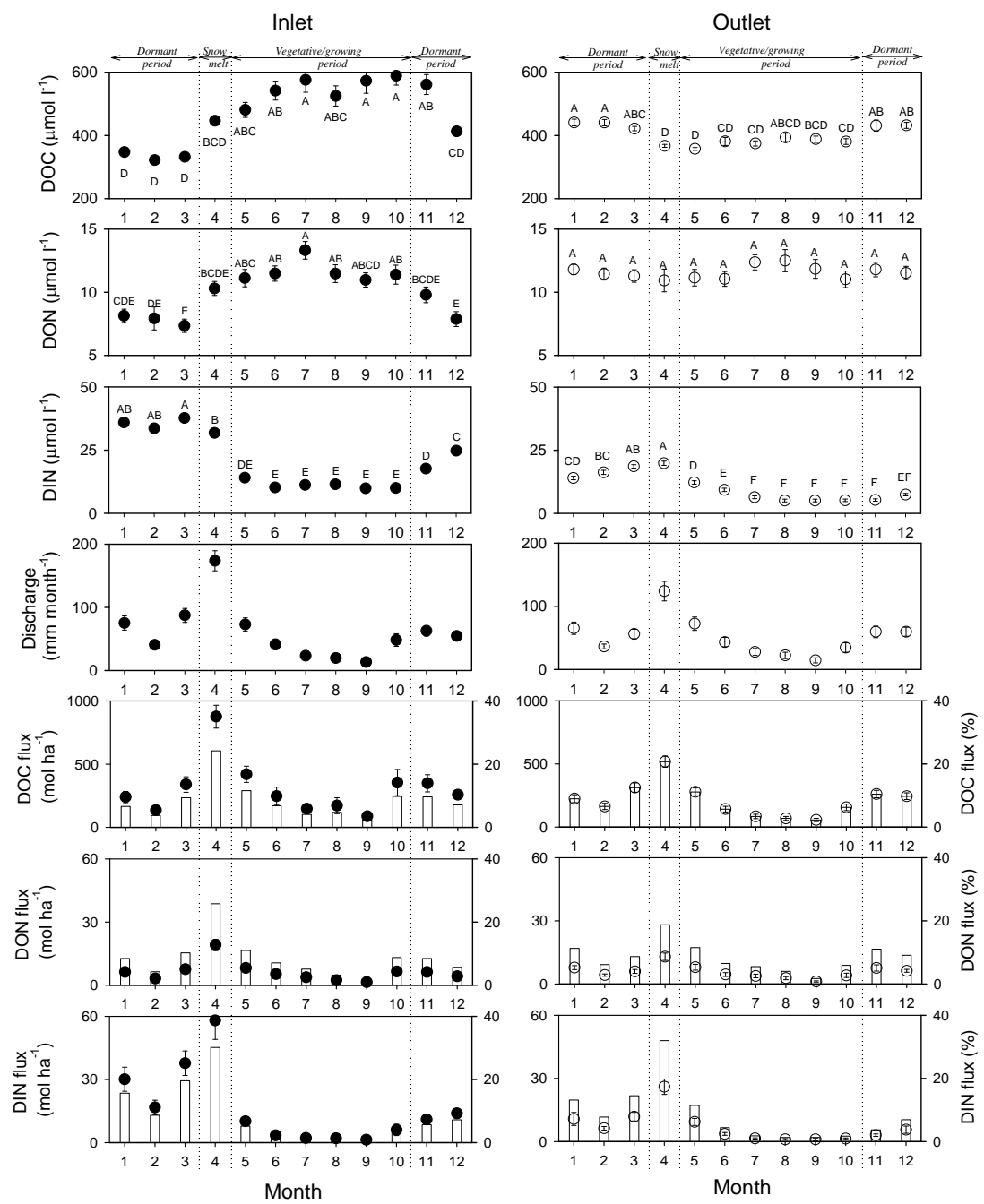

Figure 3. Monthly average discharged-weighted concentrations (error bar: SE) of DOC, DON, and DIN and monthly average flux (circle, left horizontal axis; error bars, SE) and share of the annual flux (bar, right horizontal axis) of DOC, DON, and DIN at the inlet and outlet of Arbutus Lake. Letters in upper panels indicate results of posthoc Tukey HSD test $(\alpha=0.05)$ in one-way ANOVA and the same letter among months means no significant difference. Note that specific periods that were compared are provided on the top of the figure panels.

the monthly ALTM data $\left(2501( \pm 602 \mathrm{SD}) \mathrm{mol} \mathrm{Cha}^{-1} \mathrm{yr}^{-1}\right)$ for the period from 1983 to 2012 (Tables 1 and 4).

The difference between the inlet and outlet of ADWC of DOC averaged $93 \mu \mathrm{mol} \mathrm{CL^{-1 }}$, ranging from -5 (in 2007)

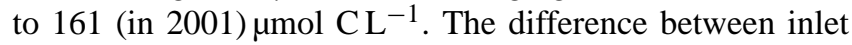
and outlet fluxes averaged $1140 \mathrm{~mol} \mathrm{Cha}^{-1} \mathrm{yr}^{-1}$ with the range of 236 to $2100 \mathrm{~mol} \mathrm{Cha}^{-1} \mathrm{yr}^{-1}$ (Table 4), indicating that DOC was decomposed or retained in the lake. The retention (\%) of DOC ranged from 9.2 to $44.1 \%$ (mean: $30.1 \%$ ). Hence, for all years there was a net decrease of DOC between the inlet and outlet.

For DON differences of ADWC and fluxes between the inlet and outlet ranged from -3.5 to $1.1 \mu \mathrm{mol} \mathrm{NL^{-1 }}$ (mean: $-1.0 \mu \mathrm{mol} \mathrm{NL} \mathrm{N}^{-1}$ ) and from -15 to $27 \mathrm{~mol} \mathrm{Nha}^{-1} \mathrm{yr}^{-1}$ (mean: $8 \mathrm{~mol} \mathrm{~N} \mathrm{ha}^{-1} \mathrm{yr}^{-1}$ ), respectively (Table 4 ). This analysis suggests that within-lake processes sometimes (particu- larly 2007) resulted in a net increase in DON through the lake in contrast to the routine net decrease in DOC. Net retention of DOC within the lake was smallest in 2007 and there was a net increase in DON during the same year (Table 4). The fraction of DON input concentrations and fluxes that changed in the lake based on fluvial DON exports ranged from -50.0 to $12.7 \%$ (mean: $-10.0 \%$ ) and from -35.7 to $31.0 \%$ (mean: $11.2 \%)$, respectively.

For DIN annual differences in concentrations and fluxes between inlet and outlet ranged from 7 to $28 \mu \mathrm{mol} \mathrm{N \textrm {N } ^ { - 1 }}$ (mean: $16 \mu \mathrm{mol} \mathrm{N} \mathrm{L}{ }^{-1}$ ) and from 60 to $183 \mathrm{~mol} \mathrm{~N} \mathrm{ha}^{-1} \mathrm{yr}^{-1}$ (mean: $120 \mathrm{~mol} \mathrm{~N} \mathrm{ha}^{-1} \mathrm{yr}^{-1}$ ), respectively (Table 4), indicating the removal of DIN in the lake. The fraction of DIN concentrations and fluxes from inlet values that were retained in the lake ranged from 42.1 to $64.3 \%$ (mean: $57.1 \%$ ) and from 45.9 to $69.4 \%$ (mean: $61.5 \%$ ), respectively. In brief, DOC, 
Table 3. Annual precipitation, inlet and outlet discharge, residence time, and hydraulic retention from 2000 to 2009 in Arbutus Lake.

\begin{tabular}{lrrrrr}
\hline Year & $\begin{array}{r}\text { Precipitation } \\
\left(\mathrm{mm} \mathrm{yr}^{-1}\right)\end{array}$ & $\begin{array}{r}\text { Inlet discharge } \\
\left(\mathrm{mm} \mathrm{yr}^{-1}\right)\end{array}$ & $\begin{array}{r}\text { Outlet discharge } \\
\left(\mathrm{mm} \mathrm{yr}^{-1}\right)\end{array}$ & $\begin{array}{r}\text { Residence time } \\
(\text { year })\end{array}$ & $\begin{array}{r}\text { Hydraulic retention } \\
(\%)\end{array}$ \\
\hline 2000 & 1323 & 885 & 733 & 0.52 & 17.2 \\
2001 & 901 & 572 & 476 & 0.80 & 16.9 \\
2002 & 902 & 545 & 541 & 0.71 & 0.9 \\
2003 & 1094 & 860 & 632 & 0.60 & 26.5 \\
2004 & 972 & 635 & 567 & 0.67 & 10.8 \\
2005 & 1296 & 728 & 539 & 0.71 & 26.0 \\
2006 & 1174 & 820 & 712 & 0.54 & 13.2 \\
2007 & 1199 & 604 & 542 & 0.70 & 10.2 \\
2008 & 1395 & 830 & 756 & 0.51 & 8.9 \\
2009 & 1153 & 641 & 471 & 0.81 & 26.5 \\
\hline Mean & 1141 & 720 & 597 & 0.66 & 15.7 \\
\hline
\end{tabular}

Table 4. Annual average of discharge-weighted concentrations, molar DOC:DON ratio, annual flux, and retention (\% and amount) of DOC, DON, and DIN at the inlet (In) and outlet (Out) of Arbutus Lake from 2000 to 2009 (I-O: Input-Output).

\begin{tabular}{|c|c|c|c|c|c|c|c|c|c|c|c|c|c|c|c|c|c|c|c|c|}
\hline \multirow[t]{2}{*}{ Year } & \multicolumn{2}{|c|}{$\begin{array}{c}\text { DOC } \\
\left(\mu \mathrm{mol} \mathrm{C} \mathrm{L}{ }^{-1}\right)\end{array}$} & \multicolumn{2}{|c|}{$\begin{array}{c}\text { DON } \\
\left(\mu \mathrm{mol} \mathrm{NL}^{-1}\right)\end{array}$} & \multicolumn{2}{|c|}{$\begin{array}{c}\text { DIN } \\
\left(\mu \mathrm{mol} \mathrm{NL}^{-1}\right)\end{array}$} & \multicolumn{2}{|c|}{$C: N$} & \multicolumn{2}{|c|}{$\begin{array}{c}\text { DOC } \\
\left(\mathrm{mol} \mathrm{Cha}^{-1} \mathrm{yr}^{-1}\right)\end{array}$} & \multicolumn{2}{|c|}{$\begin{array}{c}\text { DON } \\
\left(\mathrm{mol} \mathrm{Nha}^{-1} \mathrm{yr}^{-1}\right)\end{array}$} & \multicolumn{2}{|c|}{$\begin{array}{c}\text { DIN } \\
\left(\mathrm{mol} \mathrm{Nha}^{-1} \mathrm{yr}^{-1}\right)\end{array}$} & \multicolumn{3}{|c|}{$\begin{array}{l}\text { Retention } \\
\quad(\%)\end{array}$} & \multicolumn{3}{|c|}{$\begin{array}{c}\text { Retention } \\
\text { Amount (mol) }\end{array}$} \\
\hline & In & Out & In & Out & In & Out & In & Out & In & Out & In & Out & In & Out & DOC & DON & DIN & DOC & DON & DIN \\
\hline 2000 & 486 & 392 & 11 & 12 & 29 & 12 & 44 & 33 & 4303 & 2875 & 96 & 85 & 259 & 92 & 33.2 & 12.0 & 64.5 & 71400 & 550 & 8350 \\
\hline 2001 & 547 & 386 & 11 & 9 & 38 & 18 & 50 & 44 & 3130 & 1838 & 60 & 42 & 220 & 84 & 41.3 & 30.0 & 61.8 & 64600 & 900 & 6800 \\
\hline 2002 & 476 & 354 & 9 & 10 & 29 & 15 & 53 & 35 & 2599 & 1911 & 51 & 52 & 159 & 85 & 26.5 & -3.2 & 46.5 & 34400 & -50 & 3700 \\
\hline 2003 & 554 & 421 & 11 & 10 & 24 & 11 & 50 & 42 & 4761 & 2661 & 93 & 66 & 209 & 64 & 44.1 & 28.5 & 69.4 & 105000 & 1350 & 7250 \\
\hline 2004 & 562 & 438 & 6 & 8 & 26 & 14 & 94 & 55 & 3570 & 2481 & 40 & 47 & 165 & 80 & 30.5 & -17.6 & 51.5 & 54450 & -350 & 4250 \\
\hline 2005 & 524 & 449 & 8 & 10 & 22 & 8 & 66 & 45 & 3812 & 2420 & 60 & 54 & 157 & 42 & 36.5 & 11.2 & 73.2 & 69600 & 300 & 5750 \\
\hline 2006 & 558 & 496 & 9 & 11 & 28 & 10 & 62 & 45 & 4579 & 3529 & 75 & 78 & 230 & 71 & 22.9 & -4.7 & 69.1 & 52500 & -150 & 7950 \\
\hline 2007 & 424 & 429 & 7 & 10 & 49 & 21 & 61 & 43 & 2562 & 2326 & 42 & 57 & 295 & 112 & 9.2 & -34.8 & 62.0 & 11800 & -750 & 9150 \\
\hline 2008 & 487 & 398 & 13 & 12 & 19 & 11 & 37 & 33 & 4042 & 3012 & 109 & 91 & 159 & 86 & 25.5 & 16.6 & 45.9 & 51500 & 900 & 3650 \\
\hline 2009 & 439 & 364 & 14 & 13 & 13 & 6 & 31 & 28 & 2817 & 1712 & 87 & 60 & 89 & 29 & 39.2 & 31.2 & 67.4 & 55250 & 1350 & 3000 \\
\hline Mean & 506 & 413 & 10 & 11 & 28 & 12 & 55 & 40 & 3617 & 2477 & 71 & 63 & 195 & 75 & 30.1 & 6.9 & 61.1 & 57050 & 405 & 5985 \\
\hline
\end{tabular}

DON, and DIN decreased in the lake (mean: 57050,405 and $5985 \mathrm{~mol}$, respectively; Table 4), but the retention amount of DON decreases in the lake was less than that of DIN (Table 4).

\subsection{Factors affecting changing fluxes of DOC, DON, and DIN}

The patterns of DOC, DON, and DIN fluxes were similar for the inlet and outlet, although the concentration patterns of those solutes were different (Fig. 3), indicating that flux changes were largely caused by hydrological changes (Fig. 3, Table 5). The monthly variation of the differences in DOC, DON, and DIN concentrations and fluxes between inlet and outlet is shown in Fig. 4. The net retention of DOC flux through the lake was caused by both a decrease in discharge, particularly during snowmelt, and a decrease in DOC concentrations. In contrast DON concentrations showed no significant difference between the inlet and outlet in months except in January and December which exhibited increases in DON concentration. For the calendar year the differences of DIN concentration between the inlet and outlet increased through April after which concentrations were markedly reduced within the lake.

Results of Pearson correlation comparing percent retention of lake water and fluxes and concentrations of DOC, DON, and DIN are shown in Table 5. The percent retention of DOC was significantly related to hydraulic retention (\%), but not for DON, indicating that the decrease of DOC in the lake was related to the hydraulic changes, whereas DON retention was less affected, indicating that other factors including biotic processes were likely important. Although a significant relationship between percent retention of DOC and DON was shown, the range of DON retention ranged from negative to positive while the percent retention of DOC was always positive. Box-plots of the yearly retention of DOC, DON, and DIN in fluxes are shown in Fig. 5a, and potential sources and sinks for solutes are described in Fig. 5b.

\section{Discussion}

Our study suggests that annual DOC and DON mass balances were strikingly uncoupled as we hypothesized, and Arbutus Lake generally acted as a sink for DOC but a periodic source 


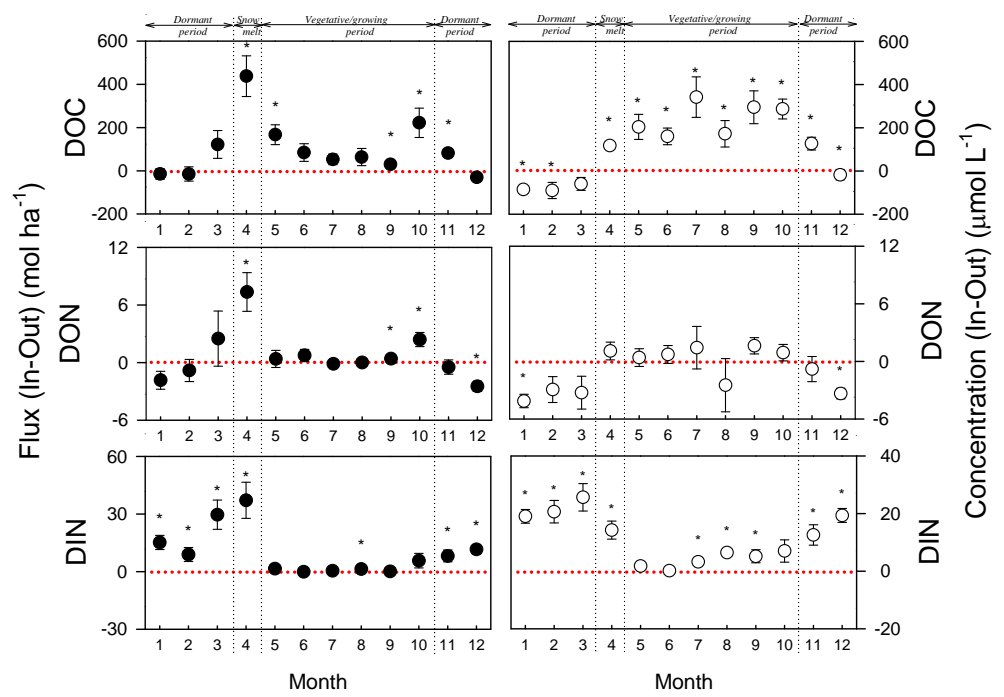

Figure 4. Monthly differences (error bars: SD) of DOC, DON, and DIN in fluxes and discharge-weighted concentrations between inlet and outlet of Arbutus Lake from 2000 to 2009. Asterisk indicates significant difference from the zero (paired $t$ test between inlet and outlet at $\alpha=0.05$ ). Note that specific periods that were compared are provided on the top of the figure panels.

(a)

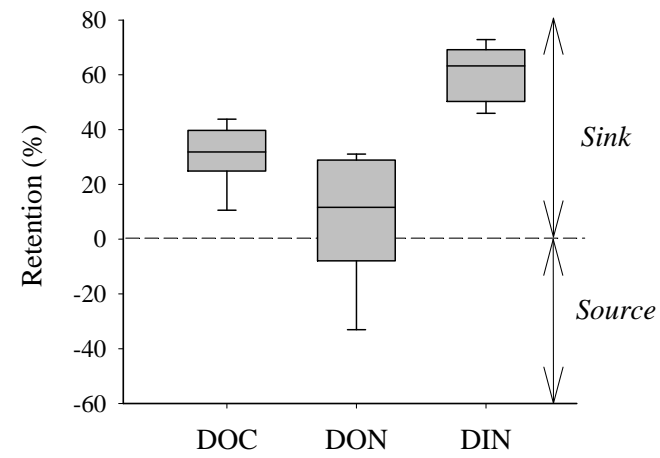

(b)

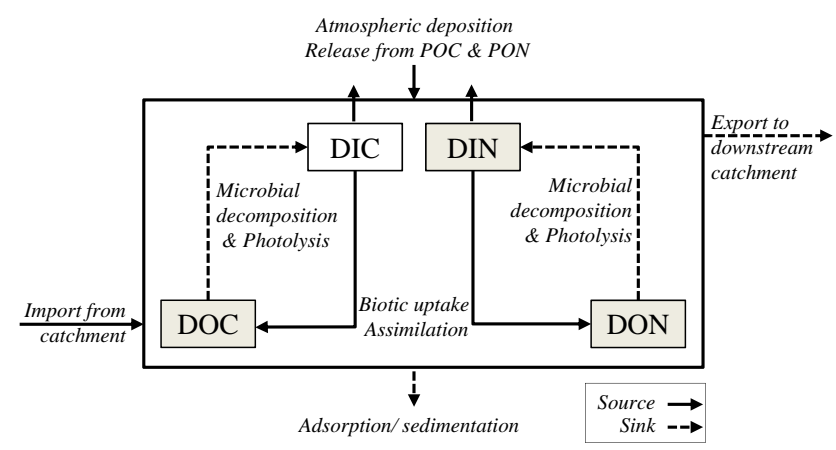

Figure 5. (a) A box plot showing annual retention ((influx-outflux)/influx)) of DOC, DON, and DIN at Arbutus Lake from 2000 to 2009. Whisker caps indicated 10th and 90th percentiles and a box showed the 25th, 50th (median), and 75th percentiles from the bottom to the top. (b) a diagram indicating sources and sinks in DOC and DON in Arbutus Lake.

for DON (Table 4, Fig. 5). For DON, internal recycling between DIN and DON might be important in affecting DON concentrations in the lake. Few studies have compared simultaneously the long-term DOC and DON dynamics in lakes. Our work indicated that the sink strength of DOC in Arbutus Lake, an oligo-mesotrophic lake, was a function of hydraulic residence (Table 5).

\subsection{Long-term change of DOC export from the lake}

Our results indicated that DOC concentrations and mass balances in Arbutus Lake varied among years but did not show significant long-term trend. These results are similar to Driscoll et al. (2007) who also found no significant trend in DOC concentrations for Arbutus Lake. However, Driscoll et al. (2007) did report that 10 of the original 16 ALTM lakes showed increased concentrations of DOC from 1982 to 2004 with a mean increase of $4.5 \pm 3.8 \mu \mathrm{mol} \mathrm{C} \mathrm{L} \mathrm{L}^{-1} \mathrm{yr}^{-1}$. The actual mechanisms causing changes of DOC concentration are not specifically known but could include biological and chemical processes (e.g., a decrease in soil DOC partitioning) and factors associated with climatic change (e.g., the hydrological change and the dry and rewetting cycle) (Driscoll et al., 2007; Fellman et al., 2011; Singh et al., 2014; von Schiller et al., 2015). Monteith et al. (2007) suggested that increases in surface water DOC are linked to decreases in sulfur deposition due to decreases in the partitioning of organic matter by soil associated with the change in $\mathrm{pH}$, aluminum and ionic strength (Ekstrom et al., 2011; Erlandsson et al., 2011; Evans et al., 2012; Mulder et al., 2001). Most of the Adirondack lakes including Arbutus Lake have shown significant decreases in sulfate concentration (Park et al., 2003; 
Table 5. Pearson correlation results $(r)$ among percent retention of lake water and fluxes and concentrations (conc.) in DOC, DON, and DIN of Arbutus Lake. A statistically significant correlation is indicated with asterisks $\left({ }^{* * *} p<0.001,{ }^{* *} p<0.01,{ }^{*} p<0.05\right)$. Percent retention of concentrations was calculated using the same equation for flux retention described in Methods.

\begin{tabular}{|c|c|c|c|c|c|c|}
\hline Percent retention & Lake water & DOC flux & DOC conc. & DON flux & DON conc. & DIN flux \\
\hline DOC flux & $0.68^{*}$ & - & & & & \\
\hline DOC conc. & & $0.75^{*}$ & - & & & \\
\hline DON flux & & $0.86^{* * *}$ & & - & & \\
\hline DON conc. & & $0.70^{*}$ & $0.69^{* *}$ & $0.92^{* * *}$ & - & \\
\hline DIN flux & $0.83^{* * *}$ & & & & & - \\
\hline DIN conc. & & & & & & $0.87^{* * *}$ \\
\hline
\end{tabular}

Driscoll et al., 2007). The effects of changes of acidic deposition on surface water, including trends in DOC concentrations, have been documented in North America (Driscoll et al., 2007) and Europe (Erlandsson et al., 2011; Evans et al., 2007; Kalbitz et al., 2000; Monteith et al., 2007, 2015; Mulder et al., 2001). However, for Arbutus Lake the effects of changes in acidic deposition may be less evident due to its relatively high $\mathrm{pH}(\sim 6.7)$ and ANC $\left(\sim 77 \mu \mathrm{eq} \mathrm{L}^{-1}\right)$ values and base status (Foster et al., 1992; Johnson and Lindberg, 1992; Mitchell et al., 2001; Chen et al., 2004; NYSERDA, 2011).

\subsection{Temporal patterns of DOC and DON concentrations in forested catchments}

Our study suggests the importance of biotic processes in affecting the seasonality of DOC and DON concentrations in forested watersheds. We observed the seasonal variation of DOC and DON concentrations such as the increase in inlet DOC and DON concentrations of the lake during the growing season with notable decreases in the dormant season (i.e., December to March) (Fig. 3). The seasonality of dissolved organic matter dynamics in forested watersheds has been shown in various studies (e.g., Aitkenhead-Peterson et al., 2003; Levia et al., 2011; Park et al., 2003). In addition, our study indicated that at the lake outlet increases in DON concentration coincided with decreases in DIN, suggesting that some DIN was converted to DON (Table 2). The monthly concentrations of DIN increased during winter and decreased from May to October, likely indicating the uptake of nitrogen as a nutrient by the biota during warmer periods of the year (Bischoff et al., 2001). Our observation of the negative relationship of DIN with DON at the inlet was consistent with the study of McHale et al. (2000) (Fig. 3, Table 2). Regarding a quality of DOC and DON from the inlet, Kang and Mitchell (2013) in this catchment showed the production of refractory and HMW DOC and DON in upland regions of the catchment, which was followed by a large increase of DOC concentrations as water was transported through downstream wetland areas. Hence, the import of the high concentrations of aromatic, refractory and HMW DOM from the inlet would likely be an important source of DOC and DON for lakes
(Kang and Mitchell, 2013; Piatek et al., 2009; Reddy and DeLaune, 2008).

Annual DOC fluxes and concentrations from the inlet (Table 4) were similar to ranges reported from other studies of Adirondack lakes (Canham et al., 2004) and across United States (580 to $6200 \mathrm{~mol} \mathrm{Cha}^{-1} \mathrm{yr}^{-1}$ and 41 to $2567 \mu \mathrm{mol}$ $\mathrm{CL}^{-1}$ ) (Aitkenhead and McDowell, 2000; Tate and Meyer, 1983; Webster et al., 2006). We observed marked increases of DOC and DON influxes during snow melt (April to May) that accounted for 35.8 and $36.7 \%$ of the annual inputs, respectively (Fig. 3). The importance of the snowmelt period has been shown in other studies of forested catchments (Hornberger et al., 1994; Boyer et al., 1997; Goodman et al., 2011; Park et al., 2005). These studies also suggest that as groundwater table rises during snow melt, high concentration of DOC and DON from pore water in upper soil horizons including the forest floor are flushed into adjacent surface waters. The export of DOM during snowmelt provides a substantial contribution to the yearly DOM mass fluxes. The export of DOC from soils to surrounding waters is controlled by many factors including hillslope connectivity (McGlynn and McDonnell, 2003), wetland area (Piatek et al., 2009), topography and the snow melt pattern (Boyer et al., 1997; Hornberger et al., 1994). At the inlet of Arbutus Lake, the increased discharge associated with snowmelt begins in early spring (e.g., March and April) resulting in increased DOC and DON concentrations that continue to increase to maximum mid-summer concentrations (Fig. 3).

Our study also showed positive relationships between discharge and the concentrations of DOC and DON during the growing season from the inlet catchment (Table 2). Previous analyses of the resultant influx of DOC and DON in the Archer Creek watershed during the growing season have shown close linkages with watershed wetness with notable increases in DOC during storms after dry antecedent periods (Inamdar et al., 2008; von Schiller et al., 2015). Studies of other lake/watersheds have found lower DOC concentrations under dry conditions (Schindler et al., 1997) with elevated DOC concentrations under wetter conditions (Hinton et al., 1997; Inamdar et al., 2011; Singh et al., 2014; Tranvik and Jansson, 2002). The increase in DOC concentrations 
in surface waters with increases in wetness of catchments has been attributed to the generation of flow paths through organic rich soil, including the forest floor (Inamdar et al., 2008), and Park et al. (2003) also showed seasonal increases of DON due to soil microbial production from December 1996 to May 1996 in the lake inlet.

\subsection{Importance of within-lake processes}

Our observations of decreasing DOC fluxes from March to November in the lake support the role of the lake as a sink of DOC (Fig. 4). Similarly subalpine lakes have been found to be a DOC sink during spring snowmelt (Goodman et al., 2011). During the warm summer, autochthonous generation of DOC might contribute to slight increases in lake DOC (Figs. 3 and 4). Nevertheless, our observations support the role of the lake as a net sink for DOC. The retention and loss of DOC within lakes may occur by microbial decomposition (Kang and Mitchell, 2013), sedimentation (Owen et al., 1999) and photolysis (Bertilsson and Tranvik, 2000; Molot and Dillon, 1997).

Our observation of the increase of DON compared to DOC within the lake indicated the importance of the DON generation processes in the $\mathrm{N}$ mass balance of this lake. When DON is mineralized to ammonium, some of the ammonium may be nitrified. This nitrate can then be utilized in assimilatory and dissimilatory reduction. Some of the organic N formed by assimilatory nitrate reduction can be found as DON (Fig. 5b). Regarding the differences in DON formation versus DOC formation in the lake, it is important to ascertain whether the rate of DON decomposition was substantially less than that of DOC or the DON generation from DIN was the major factor in maintaining relatively high concentrations of DON in the lake. From the one-year study of Kang and Mitchell (2013) in the Arbutus Lake, approximately $10 \%$ $\left(39.9 \mu \mathrm{mol} \mathrm{C} \mathrm{L}{ }^{-1}\right)$ of the total DOC was microbially decomposed, whereas $20 \%\left(2.2 \mu \mathrm{mol} \mathrm{N} \mathrm{L}{ }^{-1}\right)$ of the total DON was estimated to be bioavailable.

The removal of seston due to sedimentation can contribute to losses of DOC and DON within lake waters. Owen et al. (1999) studied seston sedimentation using traps in Arbutus Lake from September 1992 to November 1993, excluding the period from December to April. They reported on average sedimentation rate of $1.4 \mathrm{~g}$ dry mass $\mathrm{m}^{-2} \mathrm{~d}^{-1}$ and seston $\mathrm{C}$ and $\mathrm{N}$ concentrations of $16.8 \mathrm{mmol} \mathrm{C} \mathrm{g}^{-1}$ and $1.4 \mathrm{mmol}$ $\mathrm{Ng}^{-1}$ with sedimentation fluxes of $85848 \mathrm{~mol} \mathrm{Cha}^{-1} \mathrm{yr}^{-1}$ and $7154 \mathrm{~mol} \mathrm{Nha}^{-1} \mathrm{yr}^{-1}$. These relatively high sedimentation fluxes can easily account for the fluxes of DOC and DON retained in the lake observed in our study $(1140 \mathrm{~mol}$ $\mathrm{Cha}^{-1} \mathrm{yr}^{-1}$ and $8 \mathrm{~mol} \mathrm{Nha}^{-1} \mathrm{yr}^{-1}$, respectively; Table 4) and support the mechanism of removal of DOC and DON through the sedimentation of seston within the lake. Further understanding including the contribution of PON to DON increases is needed.
Since terrestrial DOM consists of HMW aromatic, chromophoric compounds (Kang and Mitchell, 2013), DOM entering the lake could also be oxidized by photolysis (Sinsabaugh and Findlay, 2003). Photochemical reactions upon exposure to ultraviolet (UV) radiation due to increased residence time in the lake can result in a considerable decrease of chromophoric DOM and the resultant modification of chemical properties of DOM (Bertilsson and Tranvik, 2000; Molot and Dillon, 1997). Kang and Mitchell (2013) observed a decrease in aromatic compounds observed from ultra violet absorbance and HMW DOC concentration in the lake suggesting the possibility of the importance of photolysis. We observed that during the ice-covered period (December to March), a net increase of DOC and DON in the outlet compared to the inlet. The exception to this occurred during March when increased discharge resulted in a large increase in DOC and DON flux into the lake (Fig. 4). Our results support the hypothesis of Pace and Cole (2002) that a decrease of photolysis during ice-cover can result in a buildup of DOC in lakes.

Like DOC the greatest difference in monthly DON fluxes between inlet and outlet occurred during the spring snowmelt. However, the magnitude of the differences in monthly fluxes between the inlet and outlet was relatively small for DON $\left(-1.0 \mu \mathrm{mol} \mathrm{NL}^{-1}\right.$ and $8 \mathrm{~mol}$ $\left.\mathrm{Nha}^{-1} \mathrm{yr}^{-1}\right)$ compared to DOC $\left(93.0 \mu \mathrm{mol} \mathrm{CL} \mathrm{CL}^{-1}\right.$ and $1,140 \mathrm{~mol} \mathrm{Cha}^{-1} \mathrm{yr}^{-1}$ ) likely indicating a contribution by autotrophs to the generation of DON in the lake over the annual cycle compared to DOC (Table 2, Fig. 4). Our observation of the decrease of DIN in the lake may support biological uptake and assimilation of DIN by algae (e.g., assimilatory nitrate reduction). The assimilation of DIN is also supported by our analysis showing the negative relationship between DIN and DON especially during the growing season (May to September) in the lake (Table 2). Our results concurred with a one year (June 1995 to May 1996) study of McHale et al. (2000) who also found a net loss of DIN and net increase of DON between the inlet and outlet of Arbutus Lake. McHale et al. (2000) also showed that changes in $\mathrm{NO}_{3}^{-}$concentrations and fluxes were greater than for DON during the growing season (June to September).

The pattern of decreasing $\mathrm{C}: \mathrm{N}$ ratios in our study with an inlet value of 55 and an outlet value of 40 is consistent with previous studies of Adirondack Lakes (including Arbutus Lake) (Ito et al., 2005, 2007) and lakes in other regions of the world (Kopáček et al., 2003; Schindler et al., 1992; Wetzel, 2001). Autochthonous DOM (with a C: N ratio of $\sim 12$; Wetzel, 2001) has been known to contribute to a pattern of decreasing the $\mathrm{C}: \mathrm{N}$ ratios from the inlet to the outlet of lakes. For Arbutus Lake, Owen et al. (1999) suggested that autochthonous production was the major contributor to seston with $\mathrm{C}: \mathrm{N}$ ratios varying from 11.6 to 11.9 and hence has values substantially lower than $\mathrm{C}: \mathrm{N}$ ratios of DOM from terrestrial sources such as leaf litter (53 to 62) and B horizon soil organic matter (22 to 29). Similarly, in 
a forested mid-Atlantic watershed, a decrease of $\mathrm{C}: \mathrm{N}$ ratios from litter to groundwater were observed largely due to a loss of DOC compared to DON (Inamdar et al., 2011). Goodman et al. (2011) also observed high temporal variability of $\mathrm{C}: \mathrm{N}$ ratios and a decrease of the $\mathrm{C}: \mathrm{N}$ ratios between inlet and outlet in five out of seven lakes studied. Other studies have suggested that changes in DON concentrations can be attributed to hydrological factors (Kaiser and Zech, 2000; Kaushal and Lewis, 2003), internal N cycles (Caraco and Cole, 2003; Kaushal and Lewis, 2005), and high DON uptake in N-limited systems (Kaushal and Lewis, 2005; Stepanauskas et al., 2000a). The increase of DON in Arbutus Lake might also be due to the production of DON from macrophyte stands (Stepanauskas et al., 2000b) which are abundant (Heady, 1942).

In the current study, one of the major findings is the observation of different retention amounts of DOC versus DON within the lake (Table 4, Fig. 5a). The lowest retention, we observed, for both DOC and DON in 2007 could likely be attributed to the biotic contributions. Although we would require measurements of primary productivity to quantify the contribution of internal biological production within the lake, the large amounts of DIN removal in the lake suggests the importance of DIN uptake and DON production in regulating TDN in the lake (Fig. 5b). In 2003, the year with highest hydraulic retention in the lake, we observed the highest retention of DOC and a high level of retention of DON (Table 4). In comparing results among years, there was a positive relationship between hydraulic retention and DOC retention, but not for DON retention (Table 5).

\subsection{Limitation and further study}

Bioavailable DON was greater than the difference between the inlet and outlet, indicating that DON was likely produced within the lake (Kang and Mitchell, 2013). In contrast, larger amounts of DOC were retained in the lake than values of biodegradable DOC, indicating that DOC might be more readily decomposed due to different processes with DON changes in the lake. Therefore, we suggest that DON generated from internal production from DIN is important. Further study is needed to understand the primary productivity for estimating DOC and DON, the microbial uptake rate of DOC (i.e., glucose) and DON (i.e., dissolved free amino acid) and the quantification of DON decomposition and retention.

Wet DIN deposition was estimated to account for $21.3 \%$ (range: 14.3 to $29.2 \%$ ) of the DIN input to Arbutus Lake from 2000 to 2009 (for example, in 2009 allochthonous DIN input from the inlet catchment, $26878 \mathrm{~mol}$ $\mathrm{N} \mathrm{yr}^{-1}=89 \mathrm{~mol} \mathrm{Nha}^{-1} \mathrm{yr}^{-1}$ (inlet DIN flux in 2009; Table 3) $\times 302$ ha (entire watershed area - lake area) and wet deposition input of DIN, $11071 \mathrm{~mol} \mathrm{~N} \mathrm{yr}^{-1}=221 \mathrm{~mol}$ $\mathrm{Nha}^{-1} \mathrm{yr}^{-1}$ (http://nadp.sws.uiuc.edu/nadpdata/annualReq. asp?site $=$ NY20) $\times 50$ ha (lake area)). If the direct deposi- tion of DIN in the lake is included in the $\mathrm{N}$ budget, $\mathrm{N}$ mass balances in the retention of DIN in Arbutus Lake is even greater (mean of DIN retention including wet DIN deposition: $64.3 \%$ ). Arbutus Lake is considered Plimited based on its molar N:P ratio of 25 (more than 7 of Redfield's ratio: calculated from TP concentration data $\left(0.44 \mu \mathrm{mol} \mathrm{PL}{ }^{-1}\right)$ from Kelting and Laxson (2014) and av-

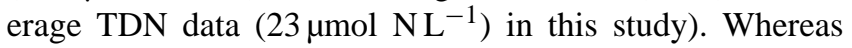
in $\mathrm{N}$-limited lakes, lake productivity is dependent on atmospheric DIN inputs that contribute to algal productivity and DON concentrations. In those $\mathrm{N}$-limited lakes, the recycling of DON might play an important role in $\mathrm{N}$ availability. Additionally, in lentic systems, since DOM bioavailability may regulate secondary production in the microbial loop (DOM $\rightarrow$ bacteria $\rightarrow$ protozoa $\rightarrow$ zooplankton), we should reconsider the importance of DON recycling.

DIC is the end product of DOC due to retention/decomposition with other fates of DOC including sedimentation, photolysis and direct uptake for biotic production. The DIC of Arbutus Lake has a mean of $\sim 115 \mu \mathrm{mol} \mathrm{CL}{ }^{-1}$ and DIC ranges from $\sim 50$ to $250 \mu \mathrm{mol} \mathrm{CL^{-1 }}$ (NYSERDA, 2011) and DIC constitutes about $25 \%$ of total dissolved carbon. Fakhraei and Driscoll (2015) summarized across the ALTM lakes which included Arbutus Lake that DIC is uniformly oversaturated with respect to the solubility of atmospheric $\mathrm{CO}_{2}$. The importance of DIC as a DOC sink needs to be studied further. Also in spite of the potential for photolysis as a mechanism removing DOC and producing DIC in lakes (e.g., Wetzel, 2003), the quantitative determination of the relative importance of this process has been difficult. Therefore, future research should consider the effect of allochthonous DOM entering lakes during the growing season on the net increase of DOC and DON in lakes during ice-cover and quantify the photolysis of DOM (e.g., approximately $10 \%$ of total respiration based on the study of Granéli et al., 1996).

\section{Conclusions}

Our study found no significant long-term changes in annual mean concentrations of DOC and DON. However, massbalances for DOC and DON between the lake inlet and outlet revealed that the lake was generally a sink for DOC (range: 11800 to $105000 \mathrm{~mol}$ ) and DIN (range: 3000 to $9150 \mathrm{~mol}$ ), but functioned as a sink or source for DON (range: -750 to $1350 \mathrm{~mol}$ ). Annual concentrations and fluxes showed strong variation as a function of the hydraulic retention time of the lake.

Our study suggests a complex interplay of both hydrological and biological factors in affecting DOC dynamics of a lake (Goodman et al., 2011), and that newly formed DON from DIN within a lake plays an important role in lake $\mathrm{N}$ dynamics (Stepanauska et al., 2000b). The enrichment of $\mathrm{N}$ in $\mathrm{DOM}$ could be a source of nutrient $\mathrm{N}$ for downstream aquatic ecosystems. This DON may also serve as a link in the sup- 
ply of a limiting $\mathrm{N}$ nutrient and subsequently contribute to productivity of $\mathrm{N}$ limited systems. Our study provides new information that DOC and DON may display substantially different biogeochemical relationships in oligo/mesotrophic lakes nested in forested watersheds, and therefore different roles for a sink behavior for DOC (which has received more attention) and a producer of DON.

Acknowledgements. We thank David Lyon (SUNY-ESF) for sampling and analytical assistance. This research was supported by US National Science Foundation (Ecosystem Studies, LTER, Hubbard Brook) and the New York State Energy Research and Development Authority (NYSERDA).

Edited by: B. A. Pellerin

\section{References}

Aitkenhead, J. A. and McDowell, W. H.: Soil C : N ratio as a predictor of annual riverine DOC flux at local and global scales, Global Biogeochem. Cy., 14, 127-138, 2000.

Aitkenhead-Peterson, J. A., McDowell, W. H., and Neff, J. C.: Sources, production, and regulation of allochthonous dissolved organic matter inputs to surface waters, in: Aquatic ecosystems: interactivity of dissolved organic matter, edited by: Findlay, S. E. G. and Sinsabaugh, R. L., Academic Press San Diego, 26-70, 2003.

Bertilsson, S. and Jones, J. B.: Supply of dissolved organic matter to aquatic ecosystems: autochthonous sources, in: Aquatic ecosystems: interactivity of dissolved organic matter, edited by: Findlay, S. E. G. and Sinsabaugh, R. L., Academic Press San Diego, 3-24, 2003.

Bertilsson, S. and Tranvik, L.: Photochemical transformation of dissolved organic matter in lakes, Limnol. Oceanogr., 45, 753-762, 2000

Bischoff, J. M., Bukaveckas, P., Mitchell, M. J., and Hurd, T.: N storage and cycling in vegetation of a forested wetland: implications for watershed N processing, Water Air Soil Poll., 128, 97-114, 2001.

Boyer, E. W., Hornberger, G. M., Bencala, K. E., and McKnight, D. M.: Response characteristics of DOC flushing in an alpine catchment, Hydrol. Process., 11, 1635-1647, 1997.

Campbell, J. L., Hornbeck, J. W., McDowell, W. H., Buso, D. C., Shanley, J. B., and Likens, G. E.: Dissolved organic nitrogen budgets for upland, forested ecosystems in New England, Biogeochemistry, 49, 123-142, 2000.

Canham, C. D., Pace, M. L., Papaik, M. J., Primack, A. G. B., Roy, K. M., Maranger, R. J., Curran, R. P., and Spada, D. M.: A spatially explicit watershed-scale analysis of dissolved organic carbon in Adirondack lakes, Ecol. Appl., 14, 839-854, 2004.

Caraco, N. F. and Cole, J. J.: The importance of organic nitrogen production in aquatic systems: A landscape perspective, in: Aquatic ecosystems: interactivity of dissolved organic matter, edited by: Findlay, S. E. G. and Sinsabaugh, R. L., Academic Press San Diego, 263-279, 2003.

Chen, L., Driscoll, C. T., Gbondo-Tugbawa, S. S., Mitchell, M. J., and Murdoch, P. S.: The application of an integrated biogeo- chemical model (PnET-BGC) to five forested watersheds in the Adirondack and Catskill regions of New York, Hydrol. Process., 18, 2631-2650, 2004.

Driscoll, C. T. and van Dreason, R.: Seasonal and long-term temporal patterns in the chemistry of Adirondack lakes, Water Air Soil Poll., 67, 319-344, 1993.

Driscoll, C. T., Fuller, R. D., and Simone, D. M.: Longitudinal variations in trace metal concentrations in a northern forested ecosystem, J. Environ. Qual., 17, 101-107, 1988.

Driscoll, C. T., Driscoll, K. M., Roy, K. M., and Mitchell, M. J.: Chemical response of lakes in the Adirondack region to declines in acidic deposition, Environ. Sci. Technol., 37, 20362042, 2003.

Driscoll, C. T., Driscoll, K. M., Roy, K. M., and Dukett, J.: Changes in the chemistry of lakes in the Adirondack region of New York following declines in acidic deposition, Appl. Geochem., 22, 1181-1188, 2007.

Ekstrom, S. M., Kritzberg, E. S., Kleja, D. B., Larsson, N., Nilsson, P. A., Graneli, W., and Bergkvist, B.: Effect of acid deposition on quantity and quality of dissolved organic matter in soil-water, Environ. Sci. Technol., 45, 4733-4739, 2011.

Erlandsson, M., Cory, N., Fölster, J., Köhler, S., Laudon, H., Weyhenmeyer, G. A., and Bishop, K.: Increasing dissolved organic carbon redefines the extent of surface water acidification and helps resolve a classic controversy, Bioscience, 61, 614-618, 2011.

Evans, C. D., Monteith, D. T., Reynolds, B., and Clark, J. M.: Buffering of recovery from acidification by organic acids, Sci. Total Environ., 404, 316-325, 2007.

Evans, C. D., Jones, T. G., Burden, A., Ostle, N., Zieliński, P., Cooper, M. D. A., Peacock, M., Clark, J. M., Oulehle, F., Cooper, D., and Freeman, C.: Acidity controls on dissolved organic carbon mobility in organic soils, Glob. Change Biol., 18, 33173331, 2012.

Fakhraei, H. and Driscoll, C. T.: Proton and aluminum binding properties of organic acids in surface waters of the Northeastern US, Environ. Sci. Technol., 49, 2939-2947, 2015.

Fellman, J. B., Dogramaci, S., Skrzypek, G., Dodson, W., and Grierson, P. F.: Hydrologic control of dissolved organic matter biogeochemistry in pools of a subtropical dryland river, Water Resour. Res., 47, W06501, doi:10.1029/2010WR010275, 2011.

Findlay, S. E. G. and Sinsabaugh, R. L. (Eds.): Aquatic ecosystems: interactivity of dissolved organic matter, Academic Press San Diego, 2003.

Foster, N. W., Mitchell, M. J., Morrison, I. K., and Shepard, J. P.: Nutrient cycling in Huntington Forest and Turkey Lakes deciduous stands: acid and base cations, Can. J. Forest Res., 22, 167174, 1992.

Freeman, C., Evans, C. D., Monteith, D. T., Reynolds, B., and Fenner, N.: Export of organic carbon from peat soils, Nature, 412 , 785, 2001.

Freeman, C., Fenner, N., Ostle, N. J., Kang, H., Dowrick, D. J., Reynolds, B., Lock, M. A., Sleep, D., Hughes, S., and Hudson, J.: Export of dissolved organic carbon from peatlands under elevated carbon dioxide levels, Nature, 430, 195-198, 2004.

Goodman, K. J., Baker, M. A., and Wurtsbaugh, W. A.: Lakes as buffers of stream dissolved organic matter (DOM) variability: Temporal patterns of DOM characteristics in moun- 
tain stream-lake systems, J. Geophys. Res., 116, G00N02, doi:10.1029/2011JG001709, 2011.

Granéli, W., Lindell, M., and Tranvik, L.: Photo-oxidative production of dissolved inorganic carbon in lakes of different humic content, Limnol. Oceanogr., 41, 698-706, 1996.

Gregorich, E. G., Beare, M. H., Stoklas, U., and St-Georges, P.: Biodegradability of soluble organic matter in maize-cropped soils, Geoderma, 113, 237-252, 2003.

Heady, H. F.: Littoral vegetation of the lakes on the Huntington Forest, Roosevelt Wildlife Bulletin, 8, 1-37, 1942.

Hedin, L. O., Armesto, J. J., and Johnson, A. H.: Patterns of nutrient loss from unpolluted, old-growth temperate forests: evaluation of biogeochemical theory, Ecology, 76, 493-509, 1995.

Helsel, D. R., Mueller, D. K., and Slack, J. R.: Computer program for the Kendall family of trend tests, US Geological Survey Scientific Investigations Report, 4, 2005-5275, 2006.

Hinton, M. J., Schiff, S. L., and English, M. C.: The significance of storms for the concentration and export of dissolved organic carbon from two Precambrian Shield catchments, Biogeochemistry, 36, 67-88, 1997.

Hornberger, G. M., Bencala, K. E., and McKnight, D. M.: Hydrological controls on dissolved organic carbon during snowmelt in the Snake River near Montezuma, Colorado, Biogeochemistry, 25, 147-165, 1994.

Inamdar, S. P. and Mitchell, M. J.: Storm event exports of dissolved organic nitrogen (DON) across multiple catchments in a glaciated forest watershed, J. Geophys. Res., 112, G02014, doi:10.1029/2006JG000309, 2007.

Inamdar, S. P., Rupp, J., and Mitchell, M. J.: Differences in dissolved organic carbon (DOC) and nitrogen (DON) responses to storm-event and groundwater conditions in a forested western New York, J. Am. Water Resour. As., 44, 1458-1473, 2008.

Inamdar, S., Singh, S., Dutta, S., Levia, D., Mitchell, M., Scott, D., Bais, H., and McHale, P.: Fluorescence characteristics and sources of dissolved organic matter for stream water during storm events in a forested mid-Atlantic watershed, J. Geophys. Res., 116, G03043, doi:10.1029/2011JG001735, 2011.

Ito, M., Mitchell, M. J., Driscoll, C. T., and Roy, K. M.: Nitrogen input-output budgets for lake-watersheds in the Adirondack region of New York, Biogeochemistry, 72, 283-314, 2005.

Ito, M., Mitchell, M. J., Driscoll, C. T., Newton, R. M., Johnson, C. E., and Roy, K. M.: Controls on surface water chemistry in two lake-watersheds in the Adirondack region of New York: differences in nitrogen solute sources and sinks, Hydrol. Process., 21, 1249-1264, 2007.

Johnson, D. W. and Lindberg, S. E.: Atmospheric Deposition and Forest Nutrient Cycling, Springer-Verlag New York, 1992.

Kaiser, K. and Zech, W.: Sorption of dissolved organic nitrogen by acid subsoil horizons and individual mineral phases, Eur. J. Soil Sci., 51, 403-411, 2000.

Kalbitz, K., Solinger, D., Park, J. H., and Matzner, E.: Controls on the dynamics of dissolved organic matter: A review, Soil Sci., 165, 277-304, 2000

Kang, P. and Mitchell, M. J.: Bioavailability and size-fraction of dissolved organic carbon, nitrogen, and sulfur at the Arbutus Lake watershed, Adirondack Mountains, NY, Biogeochemistry, 115, 213-234, 2013.
Kaushal, S. S. and Lewis, W. M.: Patterns in the chemical fractionation of organic nitrogen in Rocky Mountain streams, Ecosystems, 6, 483-492, 2003.

Kaushal, S. S. and Lewis, W. M.: Fate and transport of organic nitrogen in minimally disturbed montane streams of Colorado, USA, Biogeochemistry, 74, 303-321, 2005.

Kelting, D. L. and Laxson, C. L.: Adirondack Lake Assessment Program: 2013 Report, Arbutus Lake, Adirondack Watershed Institute of Paul Smith's College, Report No. PSCAWI 2014-56, 2014.

Kirchman, D. L.: The contribution of monomers and other lowmolecular weight compounds to the flux of dissolved organic material in aquatic ecosystems, in: Aquatic ecosystems: interactivity of dissolved organic matter, edited by: Findlay, S. E. G. and Sinsabaugh, R. L., Academic Press San Diego, 217-241, 2003.

Kopáček, J., Hejzlar, J., Kana, J., Porcal, P., and Klementová, S.: Photochemical and biological degradation of dissolved organic carbon and its impact on alkalinity production in acidified lakes, Limnol. Oceanogr., 43, 106-117, 2003.

Levia, D. F., Carlyle-Moses, D., and Tanaka, T. (Eds.): Forest hydrology and biogeochemistry: synthesis of past research and future directions, Springer Netherlands, 2011.

Likens, G. E., Edgerton, E. S., and Galloway, J. N.: The composition and deposition of organic carbon in precipitation, Tellus B, 35, 16-24, 1983.

McGlynn, B. L. and McDonnell, J. J.: Role of discrete landscape units in controlling catchment dissolved organic carbon dynamics, Water Resour. Res., 39, 1090, doi:10.1029/2002WR001525, 2003.

McHale, M. R., Mitchell, M. J., McDonnell, J. J., and Cirmo, C.: Nitrogen solutes in an Adirondack forested watershed: importance of dissolved organic nitrogen, Biogeochemistry, 48, 165184, 2000.

Mitchell, M. J., Driscoll, C. T., and Raynal, D. J.: Temporal changes and Solute Mass Balances in an Adirondack Forested watershed, Water Air Soil Poll., 88, 355-369, 1996.

Mitchell, M. J., McHale, P. J., Inamdar, S. P., and Raynal, D. R.: Role of within-lake processes and hydrobiogeochemical changes over 16 years in a watershed in the Adirondack Mountains of New York State, USA, Hydrol. Process., 15, 1951-1965, 2001.

Mitchell, M. J., Piatek, K. B., Christopher, S., Mayer, B., Kendall, C., and McHale, P.: Solute sources in stream water during consecutive fall storms in a northern hardwood forest watershed: a combined hydrological, chemical and isotopic approach, Biogeochemistry, 78, 217-246, 2006.

Molot, L. A. and Dillon, P. J.: Photolytic regulation of dissolved organic carbon in northern lakes, Global Biogeochem. Cy., 11, 357-365, 1997.

Monteith, D. T., Stoddard, J. L., Evans, C. D., de Wit, H. A., Forsius, M., Høgåsen, T., Wilander, A., Skjelkvåle, B. L., Jeffries, D. S., Vuorenmaa, J., Keller, B., Kopácek, J., and Vesely, J.: Dissolved organic carbon trends resulting from changes in atmospheric deposition chemistry, Nature, 450, 537-540, 2007.

Monteith, D. T., Henrys, P. A., Evans, C. D., Malcolm, I., Shilland, E. M., and Pereira, M. G.: Spatial controls on dissolved organic carbon in upland waters inferred from a simple statistical model, Biogeochemistry, 123, 363-377, 2015. 
Mulder, J., De Wit, H. A., Boonen, H. W. J., and Bakken, L. R.: Increased levels of aluminum in forest soils: effects on the stores of soil organic carbon, Water Air Soil Poll., 130, 989-994, 2001.

Neff, J. C., Chapin III, F. S., and Vitousek, P. M.: Breaks in the cycle: dissolved organic nitrogen in terrestrial ecosystems, Front. Ecol. Environ., 1, 205-211, 2003.

Newton, R. M. and Driscoll, C. T.: Classification of ALSC Lakes, in: Adirondack Lakes Survey: An Interpretive Analysis of Fish Communities and Water Chemistry, 1984-87, Adirondack Lakes Survey Corporation, Ray Brook pp. 2-70-2-91, 1990.

NYSERDA: The Adirondack Long-Term Monitoring Lakes: A Compendium of Site Descriptions, Recent Chemistry and Selected Research Information, New York State Energy Research and Development Authority Report No. 11-12, 251-252, 2011.

NYSERDA: Importance of Acidic and Mercury Deposition in Relation to Climate Change in the Adirondack Mountains: Biogeochemical Responses, New York State Energy Research and Development Authority Report. No. 15-04s, 2015.

OECD: Eutrophication of waters: Monitoring, assessment and control, Organisation for Economic Co-operation and Development, Paris, 1982.

Owen, J. S., Mitchell, M. J., and Michener, R. H.: Stable nitrogen and carbon isotopic composition of seston and sediment in two Adirondack lakes, Can. J. Fish. Aquat. Sci., 56, 2186-2192, 1999.

Pace, M. L. and Cole, J. J.: Synchronous variation of dissolved organic carbon and color in lakes, Limnol. Oceanogr., 47, 333-342, 2002.

Park, J. H., Mitchell, M. J., McHale, P. J., Christopher, S. F., and Myers, T. P.: Interactive effects of changing climate and atmospheric deposition on $\mathrm{N}$ and $\mathrm{S}$ biogeochemistry in a forested watershed of the Adirondack Mountains, New York State, Glob. Change Biol., 9, 1602-1619, 2003.

Park, J. H., Mitchell, M. J., and Driscoll, C. T.: Winter-time climatic control on dissolved organic carbon export and surface water chemistry in an Adirondack forested watershed, Environ. Sci. Technol., 39, 6993-6998, 2005.

Petrone, K. C., Richards, J. S., and Grierson, P. F.: Bioavailability and composition of dissolved organic carbon and nitrogen in a near coastal catchment of south-western Australia, Biogeochemistry, 92, 27-40, 2009.

Piatek, K. B., Christopher, S. F., and Mitchell, M. J.: Spatial and temporal dynamics of stream chemistry in a forested watershed, Hydrol. Earth Syst. Sci., 13, 423-439, doi:10.5194/hess-13-4232009, 2009.

Reddy, K. R. and DeLaune, R. D. (Eds.): Biogeochemistry of wetlands: Science and applications, CRC Press, 2008.

Sarkkola, S., Nieminen, M., Koivusalo, H., Laurén, A., Kortelainen, P., Mattsson, T., Palviainen, M., Piirainen, S., Starr, M., and Finér, L.: Trends in concentrations and export of nitrogen in boreal forest streams, Boreal Env. Res., 17, 85-101, 2012.

Schindler, D. W., Stainton, M. P., Kelly, C. A., Bayley, S. E., Curtis, P. J., and Parker, B. R.: Natural and man-caused factors affecting the abundance and cycling of dissolved organic substances in Precambrian Shield lakes, Hydrobiologia, 229, 1-21, 1992.

Schindler, D. W., Curtis, P. J., Bayley, S. E., Parker, B. R., Beaty, K. G., and Stainton, M. P.: Climate-induced changes in the dissolved organic carbon budgets of boreal lakes, Biogeochemistry, 36, 928, 1997.
Siddiqui, M. S., Amy, G. L., and Murphy, B. D.: Ozone enhanced removal of natural organic matter from drinking water sources, Water Res., 31, 3098-3106, 1997.

Singh, S., Inamdar, S., Mitchell, M., and McHale, P.: Seasonal pattern of dissolved organic matter (DOM) in watershed sources: influence of hydrologic flow paths and autumn leaf fall, Biogeochemistry, 118, 321-333, 2014.

Sinsabaugh, R. L. and Findlay, S.: Dissolved organic matter: Out of the black box into the mainstream, in: Aquatic ecosystems: interactivity of dissolved organic matter, edited by: Findlay, S. E. G. and Sinsabaugh, R. L., Academic Press San Diego, 479-498, 2003.

Stepanauskas, R., Laudon, H., and Jorgensen, N. O. G.: High DON bioavailability in boreal streams during a spring flood, Limnol. Oceanogr., 45, 1298-1307, 2000a.

Stepanauskas, R., Farjalla, V. F., Tranvik, L. J., Svensson, J. M., Esteves, F. A., and Granéli, W.: Bioavailability and sources of DOC and DON in macrophyte stands of a tropical coastal lake, Hydrobiologia, 436, 241-248, $2000 \mathrm{~b}$.

Tate, C. M. and Meyer, J. L.: The influence of hydrologic conditions and successional state on dissolved organic-carbon export from forested watersheds, Ecology, 64, 25-32, 1983.

Thurman, E. M.: Organic geochemistry of natural waters, Martinus Nijhoff/Dr W. Junk Publishers, Dordrecht, p. 51, 1985.

Tranvik, L. J. and Jansson, M.: Climate change-terrestrial export of organic carbon, Nature, 415, 861-862, 2002.

von Schiller, D., Graeber, D., Ribot, M., Timoner, X., Acuña, V., Martí, E., Sabater, S., and Tockner, K.: Hydrological transitions drive dissolved organic matter quantity and composition in a temporary Mediterranean stream, Biogeochemistry, 123, 429-446, 2015.

Webster, J. R., Wallace, J. B., and Benfield, E. F.: Chapter 6. Organic processes in streams of the eastern United States, in: River and stream ecosystems of the world, edited by: Cushing, C. E., Cummins, K. W., and Minshall, G. W., University of California Press, 117-187, 2006.

Wetzel, R. G.: Limnology: Lake and River Ecosystems, 3rd Edn., Academic Press New York, 2001.

Wetzel, R. G.: Dissolved organic carbon: Detrital energetics, metabolic regulators, and drivers of ecosystem stability of aquatic ecosystems, in: Aquatic ecosystems: interactivity of dissolved organic matter, edited by: Findlay, S. E. G. and Sinsabaugh, R. L., Academic Press San Diego, 455-478, 2003.

Williamson, C. E.: What role does UV-B radiation play in freshwater ecosystems?, Limnol. Oceanogr., 40, 386-392, 1995.

Worrall, F. and Burt, T.: Predicting the future DOC flux from upland peat catchments, J. Hydrol., 300, 126-39, 2005.

Worrall, F., Burt, T., and Adamson, J.: Can climate change explain increases in DOC flux from upland peat catchments?, Sci. Total Environ., 326, 95-112, 2004. 